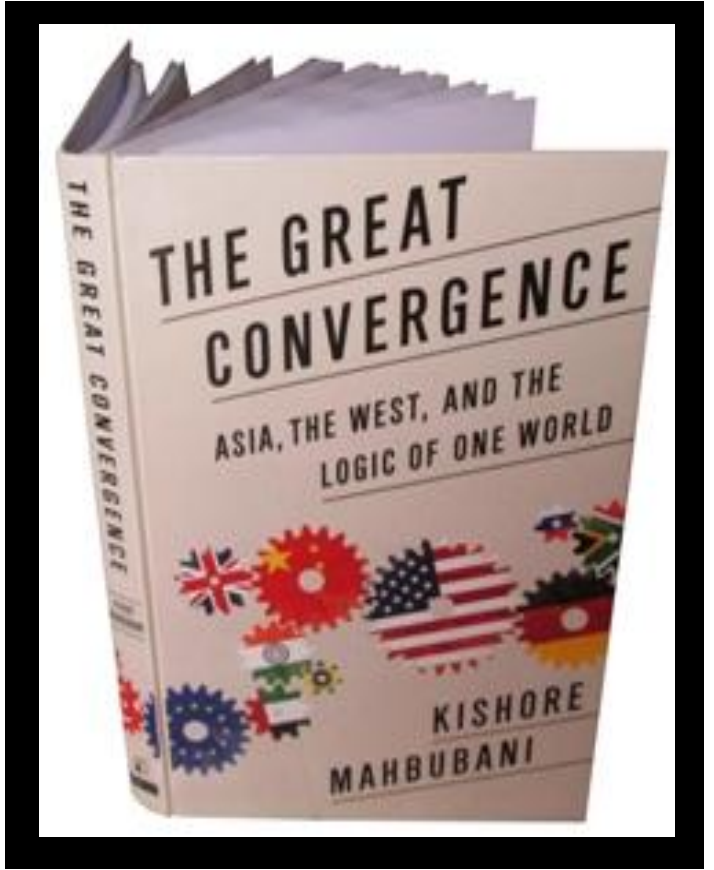

BOOK REVIEW

\section{Etika Global dalam Dunia yang Sedang Berubah: Mengelola Kebangkitan Asia dan Kemunduran Barat}

\section{Mohamad Rosyidin}

Universitas Diponegoro, Semarang

\section{Judul :}

The Great Convergence: Asia, The West, and The Logic of One World

Penulis :

Kishore Mahbubani

Penerbit :

Public Affairs

\section{Cetakan :}

I (2013)

Tebal :

315 + vii halaman

ISBN : 978-1-610-39033-0

${ }^{1}$ David Shambaugh, "Introduction: The Rise of China and Asia's New Dynamics," dalam David Shambaugh (ed.), Power Shift: China and Asia's New Dynamics (Berkeley: University of California Press, 2005), hlm. 1.

${ }^{2}$ John Mearsheimer, "China's Unpeaceful Rise," Current History (April 2006), hlm. 160.
Kebangkitan Cina, yang menurut David Shambaugh, adalah sebab utama kebangkitan Asia (Asia Rising), ${ }^{1}$ kerap dipersepsi secara negatif oleh sebagian pakar geopolitik Barat. John Mearsheimer berpendapat bahwa "Jika Cina terus mengalami pertumbuhan ekonomi yang luar biasa selama beberapa dekade mendatang, maka Amerika Serikat dan Cina akan saling bersaing dalam hal keamanan yang dapat memicu perang". ${ }^{2}$ Senada dengan itu, David Shambaugh juga berpendapat bahwa "Beijing cenderung menunjukkan perilaku yang keras dan kasar kepada banyak negara tetangganya di Asia, selain kepada Amerika Serikat dan Uni Eropa."3 Pesimisme semacam itu sangat mendominasi cara pandang Barat terhadap Cina. Akibatnya, sikap Barat kepada Cina cenderung dilandasi oleh logika ancaman ketimbang peluang kerjasama.

Kontras dengan pandangan tersebut, Kishore Mahbubani menawarkan cara pandang optimis terhadap masa depan hubungan Barat-Timur. Lewat buku ini, Mahbubani memberikan deskripsi yang tidak saja prediktif tetapi juga solutif bagi tatanan dunia yang akan datang. Sebagai seorang intelektual (Profesor dan Dekan Lee Kuan Yew, School of Public Policy Universitas Nasional Singapura) dan mantan diplomat Singapura untuk PBB, gagasan Mahbubani yang tertuang dalam buku ini mampu menyelaraskan antara pikiran akademis dan pengalaman langsung dari tangan pertama tentang bagaimana lanskap politik internasional abad-21.

Dilihat dari substansinya, buku ini merupakan kelanjutan dari buku sebelumnya yang menelaah era kebangkitan Asia dan inkompetensi Barat.4 Perbedaannya adalah jika buku sebelumnya ingin menyampaikan pesan bahwa Asia kini siap memikul tanggung jawab global dan Barat seharusnya berbagi ruang dengan Asia, buku ini beranjak lebih jauh dengan menawarkan solusi bagaimana

3 David Shambaugh, "Coping With A Conflicted China,"

The Washington Quarterly, Vol. 34, No. 1 (2011), hlm. 7.

4 Kishore Mahbubani, Asia Hemisfer Baru Dunia:

Pergeseran Kekuatan Global ke Timur yang Tak

Terelakkan, terj. Th. Bambang Murtianto (Jakarta:

Kompas Media Nusantara, 2011). 
supaya antara Barat dan Timur bisa berkolaborasi menangani pelbagai masalah global. Sederhananya, buku sebelumnya membahas pergeseran kekuatan global dari Barat ke Asia beserta implikasinya, sementara buku ini membahas kemungkinan penyatuan kepentingan antara kekuatan lama dan kekuatan baru.

Buku ini berangkat dari kenyataan bahwa dunia sedang mengalami perubahan dramatis yang ditandai oleh pergeseran kekuatan (power shift) global dari Barat ke Timur. Penurunan secara relatif kekuatan Barat oleh kebangkitan Asia seharusnya tidak perlu ditanggapi dengan penuh curiga oleh Barat. Sebaliknya, Barat harus mengakui eksistensi kekuatan-kekuatan baru yang sedang tumbuh di belahan dunia lain itu secara rasional. Alih-alih mempersiapkan diri untuk menyambut konflik baru yang bakal terjadi, Barat semestinya mengajak Timur untuk berbagi tanggung jawab global dalam menangani pelbagai problem bersama umat manusia. Tetapi kelihatannya Barat sangat sulit menerima kenyataan itu.

\section{Teori Satu Dunia}

Menurut Mahbubani, dunia sekarang ini diibaratkan seperti sebuah kapal besar yang berlayar di tengah badai di mana tak ada satu pun yang mengambil alih kemudi (hlm. 3). Sangat tidak masuk akal apabila ketika kapal tersebut mulai tenggelam karena dihempas badai, masing-masing penumpang menyelamatkan kabin mereka sendiri. Untuk bisa selamat, semua penumpang harus berupaya keras menyelamatkan kapalnya. Gambaran itu mewakili gambaran dunia saat ini di mana persoalan global tidak bisa ditangani jika masing-masing negara mementingkan dirinya sendiri. Krisis ekonomi global tahun 2008 adalah contoh bagaimana G-20 mampu mengatasi kepentingan pribadi masing-masing negara dan bersama-sama mencari solusi menanganinya.

Dunia yang semakin terintegrasi dan konsep ancaman yang tidak lagi mengenal batas-batas kedaulatan menyebabkan logika kepentingan nasional menjadi usang. Hal ini bukan berarti menghapus kepentingan nasional dan menggantinya dengan kepentingan global. Apa yang harus dilakukan adalah setiap negara perlu menyeimbangkan antara kepentingan nasional dan kepentingan global (hlm. 87). Itulah sebabnya teori-teori hubungan internasional yang sudah ada tidak cukup relevan untuk memandu 'jalan sejarah' di abad-21 seperti sekarang ini. Teori-teori tradisional seolah-olah gagap menyadari dinamika internasional yang mengalami perubahan begitu cepat, sementara pada saat yang sama teori-teori itu masih terpaku pada logika sempit kepentingan nasional yang lebih cocok dipakai untuk menjelaskan kondisi dunia abad sebelumnya.

Teori satu dunia mensyaratkan umat manusia sebagai satu kesatuan. Satu dunia tidak berarti homogenisasi. Berbeda dengan konsepsi kaum globalis yang melihat bahwa seiring dengan arus globalisasi, manusia di seluruh penjuru dunia akan mengalami penyeragaman budaya (meminjam istilah sosiolog George Ritzer, 'McDonald-isasi'). Teori satu dunia tetap mengakui dan menghormati karakteristik masing-masing budaya. Namun perbedaan itu dapat disatukan dengan kesamaan nilai fundamental yaitu etika global. Etika global bersifat lintas-batas artinya bersumber dari nilai kemanusiaan yang paling hakiki. Etika global akan menciptakan moralitas di tingkat nasional sehingga mempengaruhi tindakan negara di tingkat internasional. Jika hal ini terwujud, maka tak akan ada lagi masalah yang dipandang berdasarkan sekat-sekat kedaulatan. Masalah satu negara adalah masalah bersama seluruh dunia.

Sayangnya, menurut Mahbubani, upaya untuk mewujudkan etika global itu terhadang oleh tindakan irasional yang, ironisnya, dilakukan oleh Barat sendiri. Ketika dunia sedang berupaya mengoptimalkan instrumen multilateral guna menangani masalah-masalah global, Barat justru menggembosi kapabilitas lembaga-lembaga itu. Tindakan irasional itu misalnya kebijakan Amerika Serikat memangkas anggaran PBB sebesar 5\% pada tahun 2011 sehingga yang tadinya $\$ 5.41$ milyar menjadi $\$ 5.15$ milyar (hlm. 93). Selain itu Amerika Serikat juga melemahkan kapasitas WHO dalam memerangi penyakit di seluruh dunia. Irasionalitas Barat tidak berhenti sampai di 
situ. Badan pemeriksa tenaga atom internasional (IAEA) juga bernasib sama. Walaupun organisasi tersebut diakui sebagai alat kepentingan Barat, namun Barat justru melemahkan organisasi itu dengan menyusupkan mata-mata untuk mengumpulkan informasi intelijen terkait program nuklir negara lain (hlm. 106). Itulah alasan mengapa Iran dan Korea Utara kerap menolak tim inspeksi IAEA karena diragukan kredibilitasnya. Irasionalitas lain yang menghambat terciptanya etika global adalah kebijakan peningkatan anggaran persenjataan nuklir. Dengan anggaran rata-rata $\$ 100$ milyar per tahun untuk pengembangan dan pemeliharaan senjata nuklir, kebijakan ini merupakan "tindakan terbodoh dilihat dari sudut manapun" (hlm. 108). Jadi singkatnya, di saat dunia membutuhkan pola pikir yang berorientasi pada pencapaian kepentingan bersama, pada saat bersamaan banyak negara khususnya Barat melakukan tindakan kontraproduktif yang berorientasi pada kepentingan masing-masing.

Gagasan Mahbubani tentang teori satu dunia tidak seperti gagasan utopis kaum idealis yang melihat dunia penuh dengan harmoni. Mahbubani mengakui bahwa sekalipun konvergensi antara Barat dan Timur telah tercapai, namun konflik-konflik dalam beragam bentuknya akan tetap ada. Setidaknya ada tujuh kontradiksi global yang tidak akan hilang hingga beberapa dekade mendatang. Ketujuh kontradiksi global itu adalah kontradiksi antara kepentingan nasional dan kepentingan global, Barat dan yang lainnya (The Rest), kekuatan dominan dan kekuatan yang sedang tumbuh, kebangkitan Cina dan kawasan lain dunia, Islam dan Barat, isu lingkungan dan konsumsi global, dan pemerintah dan aktor-aktor nonnegara. Masing-masing kontradiksi tersebut akan sangat sulit didamaikan karena logika yang mendasarinya sangat berbeda bahkan bertentangan satu sama lain. Ambil contoh misalnya kontradiksi antara pemerintah dan aktor non-negara. Bagi pemerintah, logika kebijakan luar negeri adalah memperjuangkan kepentingan nasional. Sementara bagi aktor non-negara, misalnya Amnesty International atau ICRC, kepentingan mereka lebih bersifat etis karena memperjuangkan hak asasi manusia. Oleh sebab itu, supaya teori satu dunia bisa terwujud, para pembuat kebijakan seluruh dunia wajib memahami kontradiksikontradiksi tersebut dan mencari cara bagaimana menjembatani perbedaan yang bersifat inheren itu.

$$
\text { Di samping mengidentifikasi }
$$

kontradiksi global yang bakal berjalan beriringan dengan konvergensi global, Mahbubani juga menyinggung soal pengaruh geopolitik terhadap aspirasi terciptanya satu dunia. Menurutnya, konvergensi global dapat tercapai di tengah persaingan geopolitik hanya jika pola interaksi yang berlangsung tidak didominasi oleh logika kompetisi semata. Pola interaksi antar negara yang ideal adalah memadukan antara kompetisi dan kerjasama (discord and collaboration). Dalam literatur akademik, geopolitik harus sejalan dengan paradigma realis dan liberal-internasionalis (hlm. 146). Kombinasi kedua paradigma ini dapat mengurangi kecenderungan konflik internasional dengan jalan menjalin kerjasama strategis saling menguntungkan khususnya dalam bidang ekonomi. Jadi walaupun hubungan antara Cina dan Amerika Serikat diwarnai oleh hubungan permusuhan, namun pada saat bersamaan keduanya bisa menjalin kerjasama erat dalam bidang ekonomi. Begitu pula antara India dan Cina serta negara-negara anggota ASEAN. Hal ini pada gilirannya akan membuat konflik berbiaya mahal atau berdampak negatif bagi piha-pihak yang terlibat.

Lalu, pertanyaan yang sangat penting adalah: bagaimana solusi mewujudkan 'satu dunia' yang terdiri dari negara-negara berdaulat? Mahbubani berasumsi bahwa selain mengembangkan etika global, gagasan satu dunia dapat diusahakan dengan memusatkan perhatian pada tata kelola global (global governance). Tata kelola global adalah satu-satunya instrumen multilateral yang dapat diandalkan untuk mengelola kehidupan seluruh umat manusia di dunia. Tata kelola global dapat dianggap sebagai ujung tombak yang menentukan hajat hidup seluruh penduduk dunia. Solusi mewujudkan gagasan satu dunia harus dimulai dengan mereformasi tata kelola global.

Menurut Mahbubani, reformasi diprioritaskan pada institusi internasional 
yang paling sulit dilakukan perombakan yaitu DK PBB. Untuk mereformasi DK PBB Mahbubani mengajukan 'formula 7-7-7' yang berarti formasi keanggotaan DK PBB di mana ada tujuh negara yang menduduki kursi keanggotaan tetap, tujuh keanggotaan semitetap, dan tujuh keanggotaan tidak-tetap. Ketujuh anggota tetap DK PBB diharapkan adalah Amerika Serikat, Rusia, Cina, Uni Eropa, India, Brazil, dan Nigeria (hlm. 240). Ketujuh negara itu mewakili tujuh kawasan dunia yang berpenduduk paling besar. Sedangkan keanggotaan semi-tetap diduduki oleh negara-negara dengan jumlah penduduk dan PDB paling besar melalui mekanisme kompetisi. Hanya negara yang memenuhi syarat seperti demokrasi dan penegakan hukum yang bisa menduduki kursi keanggotaan semi-tetap selama periode dua tahun. Tujuh negara tidak-tetap DK PBB lainnya akan mengikuti mekanisme yang sudah ada yakni dipilih dan terbuka untuk seluruh negara anggota di luar anggota tetap dan semi-tetap. Mahbubani mengklaim formula ini lebih unggul dibanding formula yang sudah ada (hlm. 244) karena paling representatif dan dinamis sehingga paling 'demokratis' dari komposisi sebelumnya.

\section{Memerjuangkan Etika (Politik) Global}

Gagasan Mahbubani tentang etika global yang mendorong terciptanya satu dunia sebenarnya bukan gagasan baru. Pendapatnya bahwa tidak ada teori yang dapat menuntun pada kesatuan dunia agaknya melupakan satu perspektif penting dalam studi-studi internasional yakni kosmopolitanisme. Kosmopolitanisme termasuk ke dalam tradisi Teori Normatif yang mencita-citakan konsep masa depan ideal umat manusia. Salah satu teoritis penting kosmopolitanisme, Andrew Linklater, mengatakan:

"Kita hidup dalam komunitas politik di mana tradisinya adalah kepentingan sesama warga negara didahulukan, namun kita [juga] hidup dalam komunitas politik yang terpengaruh

5 Andrew Linklater, "Cosmopolitan Political

Communities in International Relations," International Relations, Vol. 16, No. 1 (2002), hlm. 135. oleh prinsip kosmopolitan bahwa seluruh umat manusia adalah setara, bahwa masing-masing individu sangat berarti dan hanya satu."

Implikasinya, kewajiban individu melampaui kedaulatan nasional di mana ia berada. Meminjam kalimat Linklater, umat manusia mengalami 'revolusi loyalitas' dari loyalitas yang menjunjung tinggi kedaulatan nasional menuju 'negara post-Westphalian'. ${ }^{6}$ Lompatan loyalitas ini menyebabkan kepentingan nasional tidak lagi relevan karena kewajiban individu bukan lagi diperuntukkan bagi negara melainkan seluruh umat manusia di manapun ia berada.

Etika global yang melekat dalam gagasan kosmopolitanisme menekankan pada individu sebagai aktor. Bagi kaum kosmopolitan negara tidak terlalu penting karena masih mengagung-agungkan konsep klasik seperti 'kedaulatan' dan 'kepentingan nasional'. Tetapi sejauh negara tetap menjadi entitas politik yang mendominasi hubungan internasional, gagasan reduksionis kosmopolitan boleh jadi belum akan menjadi kenyataan setidaknya hingga beberapa dekade mendatang. Hanya saja, gagasan bahwa kepentingan nasional bukan satu-satunya yang mendasari kebijakan luar negeri negara sepertinya semakin menguat seiring dengan menguatnya pengaruh nilai-nilai kemanusiaan yang terejawantah dalam pelbagai norma dan institusi internasional.

Satu hal penting dari gagasan Mahbubani yang perlu dikritisi adalah mengantisipasi benturan geopolitik dengan pendekatan realis dan liberal-institusionalis. Benar bahwa kedua paradigma itu sangat mendominasi interaksi antar negara; selain berkompetisi dalam hal keamanan negara juga perlu menjalin kerjasama saling menguntungkan. Namun, gagasan itu bertentangan dengan gagasan tentang etika global yang seharusnya mendasari politik internasional. Logika realis dan liberalinstitusionalis berada dalam satu kerangka berpikir yang dinamakan rasionalisme.

${ }^{6}$ Andrew Linklater, Critical Theory and World Politics: Citizenship, Sovereignty and Humanity (London: Routledge, 2007), hlm. 90. 
Rasionalisme menekankan pada pertimbangan untung-rugi. Sedangkan etika global diusung oleh paradigma sosiologis yang melihat bahwa norma lebih berperan penting ketimbang pertimbangan untung-rugi. Jadi ada semacam inkonsistensi dari gagasan Mahbubani tentang faktor apa yang dapat dipakai sebagai 'lem perekat' hubungan antar negara supaya konvergensi antara Barat dan kekuatan-kekuatan yang sedang tumbuh bisa terwujud.

Solusi yang diajukan Mahbubani untuk mereformasi DK PBB juga menyimpan masalah yang cukup serius. Sebagaimana telah dikatakannya dalam bukunya yang lain, DK PBB merepresentasikan 'aristokrasi global' karena memiliki hak istimewa sebagai 'penanggung jawab perdamaian dan keamanan dunia'.7 'Formula 7-7-7' Mahbubani barangkali sangat ideal karena sesuai dengan kondisi dunia yang sedang berubah. Namun, seperti diakui sendiri oleh Mahbubani, batu sandungan terbesar akan datang dari Amerika Serikat (hlm. 243). Amerika Serikat selama ini sudah cukup nyaman dengan komposisi keanggotaan yang sudah ada. Resistensi dipastikan juga akan muncul dari Inggris dan Perancis yang bakal kehilangan statusnya sebagai anggota tetap. Pernyataaan Mahbubani bahwa, "Perancis dan Inggris akan memperoleh sedikit keuntungan dengan menjadi anggota tetap organisasi [DK PBB] yang terus mengalami kehilangan legitimasinya itu" (hlm. 245) tampak seperti sebuah kalimat 'Nina bobok' (lullaby) untuk membujuk kedua negara agar bersedia melepaskan posisinya.

Ada tiga alasan mengapa resistensi Perancis dan Inggris akan dirasa cukup kuat. Pertama, faktor sejarah di mana Perancis dan Inggris adalah pemenang perang yang menjadi

7 Kishore Mahbubani, Can Asian Think? (Singapore: Marshall Cavendish International, 2009), hlm. 222-223. 8 Ana Echagüe and Barah Mikail, "The Middle East Conundrum," dalam Giovanni Grevi and Daniel Keohane (eds.), Challenges for European Foreign Policy in 2013: Renewing the EU's role in the world (Madrid: FRIDE, 2013), hlm. 63 sumber kebanggaan nasional. Tidak ada satu pun negara di dunia yang mau menghapus memori sejarahnya yang membanggakan. Kedua, Perancis dan Inggris adalah negara nuklir yang tidak ingin kehilangan status istimewa sebagai negara besar di DK PBB. Ketiga, dalam konteks kebijakan luar negeri Uni Eropa masih belum solid. Sebagai contoh, kebijakan Uni Eropa dalam isu Timur Tengah sangat terfragmentasi. ${ }^{8}$ Dalam hal peran Uni Eropa, Perancis ingin Eropa lebih kuat sedangkan Inggris ingin supaya Eropa bersikap ambivalen. Dalam isu peace keeping Uni Eropa tampak solid, tetapi dalam isu penggunaan militer Uni Eropa terpecah. 9 Meskipun tampak realistis, gagasan reformasi DK PBB akan melalui jalan terjal.

Terlepas dari itu, buku ini layak menjadi referensi para pembuat kebijakan guna meningkatkan kesadaran bahwa etika global sudah waktunya menjadi landasan dalam merumuskan kebijakan luar negeri. Pelbagai persoalan dunia sekarang ini tidak bisa diatasi hanya dengan mengandalkan upaya satu negara. Kolaborasi internasional mutlak diperlukan jika kita masih ingin selamat dari bencana global. Cara pandang yang optimistis dari buku ini sekaligus membuka pikiran kita bahwa meskipun antara Barat dan Timur adalah dua peradaban yang berbeda, namun hal itu tidak akan berujung pada 'benturan antar peradaban' sebagaimana diramalkan oleh Samuel Huntington lebih dari dua dekade silam. Optimisme buku ini juga menyangkal pesimisme tesis 'Tidak Ada Satu Dunia' (No-One's World) yang berasumsi bahwa pusat-pusat kekuatan global seperti Amerika Serikat, Uni Eropa, Brazil, India, Cina, Rusia akan saling berbenturan dan tak ada satu kekuatan yang akan menang. ${ }^{10}$ Dunia semakin kompleks dengan masalah yang

9 Ulrich Krotz and Richard Maher, "International Relations Theory and the Rise of European Foreign and Security Policy," World Politics, Vol. 63, No.3 (July 2011), hlm. 549.

${ }_{10}$ Charles Kupchan, "No-One's World: The West, The

Rest, and The Coming Global Turn" seperti dikutip dalam Ewan Harrison and Sara McLaughlin Mitchell, The 
semakin pelik untuk dipecahkan sendirisendiri. Negara-negara harus menyatukan persepsi dan kepentingan mengatasi bahaya di depan mata secara bersama-sama.

\section{Daftar Pustaka}

Echagüe, Ana and Barah Mikail. (2013) "The Middle East Conundrum," dalam Giovanni Grevi and Daniel Keohane (eds.), Challenges for European Foreign Policy in 2013: Renewing the EU's role in the world. Madrid: FRIDE.

Harrison, Ewan and Sara McLaughlin Mitchell. (2014) The Triumph of Democracy and The Eclipse of The West. New York: Palgrave Macmillan.

Krotz, Ulrich and Richard Maher. (2011) "International Relations Theory and the Rise of European Foreign and Security Policy," World Politics, Vol. 63, No. 3 (July), pp. 548-579.

Linklater, Andrew. (2002) "Cosmopolitan Political Communities in International Relations," International Relations, Vol. 16, No. 1, pp. 135-150. . (2007) Critical Theory and World Politics: Citizenship, Sovereignty and Humanity. London: Routledge.

Mahbubani, Kishore. (2009) Can Asian Think? Singapore: Marshall Cavendish International.

. (2011) Asia Hemisfer Baru Dunia: Pergeseran Kekuatan Global ke Timur yang Tak Terelakkan, terj. Th. Bambang Murtianto. Jakarta: Kompas Media Nusantara.

Mearsheimer, John. (2006) "China's Unpeaceful Rise," Current History (April), pp. 160-162.

Shambaugh, David. (2005) "Introduction: The Rise of China and Asia's New Dynamics," dalam David Shambaugh (ed.), Power Shift: China and Asia's New Dynamics. Berkeley: University of California Press.
. (2011) "Coping With A Conflicted China," The Washington Quarterly, Vol. 34, No. 1, pp. 7-27.

* Mohamad Rosyidin adalah dosen di program studi Ilmu Hubungan Internasional FISIP Universitas Diponegoro, Semarang. Memperoleh gelar Master of Arts dari Universitas Gadjah Mada pada tahun 2013 dan mengkhususkan minat penelitian dalam bidang analisis politik luar negeri, teori-teori hubungan internasional, keamanan internasional, politik luar negeri Indonesia, dan metode penelitian. Karya-karyanya telah dipublikasikan di berbagai jurnal ilmiah nasional seperti Global: Jurnal Politik Internasional Universitas Indonesia (2010), Global \& Strategis Universitas Airlangga (2011 dan 2014), Swara Politika Universitas Jenderal Soedirman (2012), Jurnal Universitas Paramadina (2012, 2013, dan 2014), Analisis CSIS (2012), Andalas Journal of International Studies Universitas Andalas (2012), Jurnal Penelitian Politik (P2P) LIPI (2013), Jurnal Hubungan Internasional Universitas Airlangga (2013), Multiversa: Journal of International Studies Universitas Gadjah Mada (2013), Jurnal Luar Negeri Kementerian Luar Negeri RI (2014), Jurnal Kajian Wilayah LIPI (2014) dan menulis di kolom opini Kompas (2011), Republika (2014), dan media online. Sedangkan karya lain berupa buku berjudul The Power of Ideas: Konstruktivisme dalam Studi Hubungan Internasional (Tiara Wacana, akan terbit) dan Sanksi Ekonomi Internasional: Teori dan Implementasi (Ombak, akan terbit). Penulis dapat dihubungi melalui mohamad.rosyidin@gmail.com. 